\title{
Pengaruh Model Pembelajaran Problem Solving Terhadap Kemampuan Berfikir Kritis, Motivasi Belajar, dan Hasil Belajar Ekonomi Siswa Kelas X SMAN 1 Masbagik
}

\author{
${ }^{1}$ Zalia Muspita ${ }^{2}$ Isfi Sholihah \\ 1,2, Prodi pendidikan ekonomi, FISE Universitas Hamzanwadi \\ Email: zmuspita@gmail.com
}

Received: 27 Januari, 2019; Accepted: 20 Maret, 2019; Published: 26 Juni, 2019

\begin{abstract}
Abstrak
Tujuan penelitian ini adalah untuk mengetahui pengaruh secara simultan, model pembelajaran problem solving terhadap kemampuan berpikir kritis, motivasi belajar, dan hasil belajar Ekonomi siswa kelas X SMAN 1 Masbagik - Lombok Timur. Penelitian ini merupakan penelitian eksperimen semu. Data penelitian dikumpulkan dengan tes kemampuan berpikir kritis, angket motivasi belajar, dan tes hasil belajar Ekonomi siswa. Pengujian hipotesis dilakukan dengan menggunakan analisis Manova. Hasil penelitian menunjukkan bahwa, (1) Terdapat pengaruh penerapan model pembelajaarn problem solving terhadap kemampuan berfikir kritis siswa kelas X SMAN 1 Masbagik. (2) Terdapat pengaruh model pembelajaarn problem solving terhadap motivasi belajar siswa kelas X SMAN 1 Masbagik. (3) Terdapat pengaruh model pembelajaran problem solving terhadap hasil belajar Ekonomi siswa kelas X SMAN 1 Masbagik. (4) Terdapat pengaruh secara simultan penerapan model pembelajaarn problem solving terhadap kemampuan berfikir kritis siswa, motivasi dan hasil belajar Ekonomi siswa kelas X SMAN 1 Masbagik.

Kata kunci: model pembelajaran problem solving, kemampuan berpikir kritis, motivasi belajar, hasil belajar Ekonomi.
\end{abstract}

\footnotetext{
Abstract

The purpose of this study was to determine the effect of simultaneous model of problemsolving on critical thinking skills, motivation and learning outcomes of Economic studies students of the sevent grade at Senior high school number 1 Masbagik - East Lombok. This study is a quasi-experimental. Data were collected with the critical thinking skills tests, questionnaires, and tests student learning outcomes. Overall the data and hypothesis testing is done using Manova analysis.

Based on the above results, the conclusion can be formulated as follows: (1) In a partial implementation of the model problem solving have a relationship with the critical thinking skills of Economi students in the sevent grade at Senior high school number 1 Masbagik - East Lombok. (2) In a partial implementation of the model-solving have relationship problems with the sevent grade at Senior high school number 1 Masbagik - East Lombok. (3) In a partial implementation of the model-solving have relationship problems with motivation to learn in the sevent grade at Senior high school number 1 Masbagik - East Lombok. (4) In the
} 
DOl: http://dx.doi.org/10.29408/jpek.v3i1.1525

simultaneous application of problemsolving models have a relationship with the students' critical thinking skills, motivation and learning outcomes of social studies students in the sevent grade at Senior high school number 1 Masbagik - East Lombok.

Keywords: Critical Thinking Skills, Learning Outcomes Of Ecomomic, Model Of Problem Solving, Motivation, 


\section{PENDAHULUAN}

Pendidikan memegang peranan yang sangat penting dalam kelangsungan hidup suatu bangsa. Pada dasarnya pendidikan merupakan "pengubahan sikap dan tingkah laku individu dengan positif pada natural individu yang bersangkutan" (Wingkel, 1999:24). Pendidikan juga merupakan salah satu ukuran kualitas suatu kehidupan bangsa, karena tingkat pendidikan dapat menunjukkan kualitas sumberdaya yang dimiliki oleh suatu bangsa. Dewasa ini, pendidikan telah mengalami perkembangan yang sangat pesat, informasi dan komunikasai juga berkembang setiap saat. Hal itu mengakibatkan adanya persaingan yang sangat ketat di dunia pendidikan, untuk menghadapinya diperlukan kualitas pendidkan yang bermutu dan semakin meningkat. Pembelajaran akan dikatakan berkualitas apabila proses pembelajarannya melibatkan siswa secara utuh.

Pemerintah telah melakukan berbagai upaya untuk meningkatkan kualitas pendidikan di Indonesia, salah satunya adalah penyempurnaan kurikulum yang lebih menekankan pada keterlibatan siswa dalam pengembangan kompetensi yang dimiliki oleh siswa, kurikulum yang dimaksud adalah Kurikulum Berbasis Kompetensi (KBK) 2004 sebelum ditetapkannya Kurikulum Tingkat Satuan Pendidikan (KTSP) 2006. Pada pelaksanaan kurikulum ini siswa diharapkan lebih terlibat dalam proses belajar mengajar, guru hanya berperan sebagai fasilitator saja dan siswa dituntut untuk lebih aktif peranannya. Hal tersebut sesuai dengan salah satu prinsip pengembangan Kurikulum Tingkat Satuan Pendidikan (KTSP) 2006, bahwa kurikulum dikembangkan berdasarkan beberapa prinsip yaitu: "1) berpusat pada potensi, pengembangan dan kebutuhan, 2) tanggap terhadap ilmu pengetahuan, teknologi, dan seni, kepentingan peserta didik dan lingkungannya. (BNSP, 2006)

Sejalan dengan hal tersebut, maka dalam proses pembelajaran diperlukan adanya pembelajaran inovatif yang mampu mengembangkan kemampuan berfikir siswa, meningkatkan motivasi belajar, dan meningkatkan hasil belajar siswa pada mata pelajaran Ekonomi. Akan tetapi, pembelajaran yang inovatif jarang dilakukan. Sering sekali guru hanya menjelaskan, memberikan ceramah, dan memberikan hafalan pada siswa sehingga membuat siswa jenuh pada mata pelajaran Ekonomi. 
Permasalahan yang sering muncul pada siswa maupun guru di sekolah adalah siswa merasa bosan pada pelajaran Ekonomi karena terlalu banyak materi yang berkaitan dengan hafalan dan siswa tidak mampu memahami materi sepenuhnya. Sehingga kemampuan berfikir siswa terbatas pada hafalan dan siswa tidak mampu memecahkan permasalahan yang ada. Selain itu juga guru seringkali memberikan ceramah satu arah tanpa memberikan kesempatan pada siswa untuk mengemukakan pendapat, berdiskusi dengan temannya, dll.

Akibatnya pembelajaran Ekonomi di sekolah hanya bersifat hafalan bukan melatih kemampuan berfikir siswa yang menyebabkan kurangnya motivasi belajar Ekonomi yang ditandai dengan gejala-gejala 1) tidak mengerjakan tugas atau pekerjaan rumah yang diberikan oleh guru,2) siswa tidak memperhatikan guru yang sedang menerangkan pelajaran Ekonomi, 3) siswa sering sekali mengganggu temannya yang sedang mendengarkan pelajaran, 4) siswa mengajak ngobrol temannya yang sedang mendengarkan pelajaran. Sehingga hasil belajar Ekonomi siswa menjadi rendah

Berdasarkan uraian di atas, perlu adanya perbaikan dalam proses pembelajaran. Siswa membutuhkan pembelajaran yang lebih inovatif. Bentuk pembelajaran yang mampu membantu mereka dalam proses pembelajaran, oleh karena itu guru perlu memperbaiki pola pembelajaran dan mengupayakan sebuah inovasi dalam pembelajaran. Salah satunya dengan pembelajaran problem solving. Dimana pembelajaran tersebut mampu membawa siswa menggunakan pengetahuan yang diperoleh di kelas untuk menyelesaikan masalah-masalah baru yang belum pernah dihadapi, serta memiliki tanggung jawab yang lebih terhadap belajarnya seiring dengan peningkatan pengalaman dan pengetahuan mereka..

Pembelajaran Problem solving adalah " suatu pendekatan pengajaran yang menggunakan masalah dunia nyata sebagai suatu konteks bagi siswa untuk belajar tentang cara berpikir kritis dan keterampilan pemecahan masalah, serta untuk memperoleh pengetahuan dan konsep yang esensial dari materi pelajaran" (Nurhadi, dkk. 2004:56).

Panen, dkk (2001:85) mengemukakan berpikir kritis merupakan sebuah proses yang terarah dan jelas yang digunakan dalam kegiatan mental seperti 
memecahkan masalah, mengambil keputusan, membujuk, menganalisis asumsi dan melakukan penelitian ilmiah. Berpikir kritis adalah kemampuan untuk berpandapat dengan cara yang terorganisasi. Menurut Johnson (2002:182) berpikir kritis merupakan "kemampuan untuk mengevaluasi secara sistematis bobot pendapat pribadi dan pendapat orang lain". Sedangkan berpikir kreatif adalah "kegiatan mental yang memupuk ide-ide asli dan pemahaman-pemahaman baru". (Johnson 2002:183).

Berpikir kritis dan kreatif memungkinkan siswa untuk mempelajari masalah secara sistematis, menghadapi banyak rintangan dengan cara yang terorganisasi, merumuskan pertanyaan inovatif, dan merancang solusi yang tepat. Apabila hal tersebut dilatih secara terus menerus, di duga dapat meningkatkan motivasi belajar siswa.

Sebagai upaya meningkatkan motivasi belajar siswa sutanto (2005) mengemukakan enam macam tingkah laku yang dapat diamati antara lain: 1) Perhatian, motivasi belajar siswa tinggi apabila mereka memusatkan perhatian pada kegiatan belajar lebih besar daripada tingkah laku yang bukan belajar. 2) Waktu belajar, siswa mempunyai motivasi tinggi jika siswa mengahbiskan waktu yang cukup untuk kegiatan belajar. 3) Usaha, siswa mempunyai motivasi tinggi jika mereka bekerja secara intensif, mengeluarkan banyak energi dan kemampuan untuk menyelesaikannya. 4) Irama perasaaan, siswa mempunyai motivasi tinggi jika siswa merasa gembira, mempunyai keyakinan diri dan tegar pada situasi yang ada. 5) Eksistensi, dalam hal ini motivasi belajar ditandai dengan apakah siswa melakukan kegiatan-kegiatan belajar pada jam-jam bebas pelajaran. 6) Penampilan, motivasi belajar ditunjukkan dengan diselesaikannya tugas belajar.

Motivasi belajar siswa yang akan diamati dan ditingkatkan dalam penelitian ini adalah motivasi ekstrinsik dimana motivasi ekstrinsik merupakan motivasi yang fungsinya dirangsang dari luar diri siswa. Dalam penelitian ini yang merupakan alat perangsang adalah pembelajaran berbasis masalah. Dan diharapkan setelah motivasi ekstrinsik meningkat, dapat pula meningkatkan motivasi intrinsik siswa (motif-motif yang menjadi aktif atau berfungsinya tidak perlu dirangsang dari luar, 
karena dalam diri setiap individu sudah ada dorongan untuk melakukan sesuatu), sehingga diharapkan mampu meningkatkan hasil belajar Ekonomi siawa.

Siswa yang memiliki keampuan berfikir kritis tinggi dan motivasi belajar yang tinggi akan dapat meningkatkan hasil belajar yang baik dan sebaliknya siswa yang kurang motivasi dalam proses pembelajaran akan memperoleh hasil belajar yang tidak baik.

Berdasarkan uraian di atas, dibutuhkan pembuktian secara empiris melalui eksperimen mengenai pengaruh model pembelajaran Problem Solving terhadap kemampuan berfikir kritis, motivasi belajar, dan hasil belajar Ekonomi siswa kelas X SMAN 1 Masbagik.

\section{METODE PENELITIAN}

Dilihat dari fokus masalah dan kaitan antar variabel yang dilibatkan dalam penelitian, penelitian ini termasuk dalam kategori penelitian eksperimen menggunakan post test only control group design. Variabel dalam penelitian ini yaitu: pembelajaran Problem Solving dan pembelajaran konvensional sebagai variabel bebas, kemampuan berfikir kritis siswa, motivasi belajar siswa dan hasil belajar Ekonomi sebagai variabel terikatnya

Populasi penelitian ini adalah seluruh siswa kelas X SMAN 1 Masbagik yang berjumlah 324 orang dari sembilan kelas. Dimana dari 9 kelas yang ada semuanya dinyatakan sama setelah dilakukan uji setara. Sampel dalam penelitian ini diambil secara acak (random sampling). Dalam penelitian ini dua kelas diambil sebagai sampel yaitu kelas $\mathrm{X}-4$ sebagai kelas eksperimen dan kelas $\mathrm{X}-5$ sebagai kelas kontrol.

Instrumen penelitian yang digunakan dalam penelitian ini adalah instrumen yang berbentuk tes kemampuan berfikir kritis yang diadaptasi dari California critcal Thingking Skill Test untuk mengukur kemampuan berfikir kritis siswa, angket untuk mengukur motivasi belajar dan tes pilihan ganda yang digunakan untuk mengukur hasil belajar Ekonomi siswa.

Sebelum dilakukan penelitian terlebih dahulu dilakukan uji validitas dan reliabilitas instrumen dengan bantuan SPSS-PC 20.0 for Windows. 
Hasil validitas tes kemampuan berfikir kritis yang dilakukan pada siswa kelas X dengan 55 responden dengan 22 butir soal. Setelah dilakukan perhitungan validitas soal dengan menggunakan korelasi produc moment di peroleh 19 butir soal dinyatakan valid dan 3 butir soal tidak valid. Realibiltas tes kemampuan berfikir kritis adalah 0.84 dengan kriteria sangat tinggi. Berdasarkan hasil validitas dan realibilitas tes kemampuan berfikir kritis, dari 22 soal dipilih 19 butir soal untuk mengetahui kemampuan berfikir kritis siswa.

validitas tes motivasi yang dilakukan pada siswa kelas XI dengan 55 responden dengan 20 butir soal. Setelah dilakukan perhitungan validitas soal dengan menggunakan korelasi produc moment di peroleh 20 butir soal dinyatakan valid. Realibiltas tes motivasi belajar siswa adalah 0.80 dengan kriteria sangat tinggi. Berdasarkan hasil validitas dan realibilitas tes motivasi belajar siswa, dari 20 soal dipilih 20 butir soal untuk mengetahui motivasi belajar siswa.

Uji validitas tes hasil belajar Ekonomi yang dilakukan pada siswa kelas XI dengan 55 responden dengan 30 butir soal. Setelah dilakukan perhitungan validitas soal dengan menggunakan korelasi produc moment di peroleh 30 butir soal dinyatakan valid. Realibilitas hasil belajar Ekonomi siswa adalah 0.98 dengan kriteria sangat tinggi. Berdasarkan hasil validitas dan realibilitas hasil belajar Ekonomi siswa, dari 30 soal dipilih 30 butir soal untuk mengetahui hasil belajar Ekonomi siswa.

Hipotesis dalam penelitian ini, yaitu: 1) terdapat pengaruh penerapan model Problem solving terhadap kemampuan berfifir kritis Ekonomi siswa kelas X SMAN 1 Masbagik, 2). terdapat pengaruh penerapan model pembelajaran problem solving terhadap motivasi belajar Ekonomi siswa kelas X SMAN 1 Masbagik, 3). terdapat pengaruh penerapan model pembelajaran problem solving terhadap hasil belajar Ekonomi siswa kelas X SMAN 1 Masbagik, 4). secara simultan terdapat pengaruh penerapan model pembelajaran problem solving terhadap kemampuan berfifir kritis, motivasi serta hasil belajar Ekonomi siswa kelas X SMAN 1 Masbagik

Untuk menguji hipotesis 1.2 dan 3 menggunakan uji T - Tes model Sampel Independen Tes. Sedangkan hipotesis 4 dalam penelitian ini digunakan MANOVA 
dengan analisis Pillea Trace, Wilk Lambda, Hotelling Trace, Roy's Largest Root. Hasil analisis menunjukkan harga $\mathrm{F}$ lebih kecil dari 0,05 artinya data signifikan. Jadi terdapat pengaruh kemampuan berfikir kritis, motivasi dan hasil belajar Ekonomi antara siswa yang mendapatkan tretmen dan siswa yang tidak. Untuk menganalisis data dalam penelitian ini menggunakan SPSS 20.0 For Windows.

\section{HASIL PENELITIAN DAN PEMBAHASAN}

Mengacu pada hasil uji prasyarat, yakni uji normalitas dan homogenitas varian dapat disimpulkan bahwa data dari semua kelompok berasal dari data berdistribusi normal dan mempunyai varians yang sama atau homogen. hasil bahwa semua data berdistribusi normal.

Hasil penelitian menunjukkan data sebagai berikut.

Tabel 1. Rekapitulasi Hasil Perhitungan Skor Kemampuan Berfikir Kritis, Motivasi Belajar dan Hasil Belajar Ekonomi Siswa

\begin{tabular}{cllllll}
\hline $\begin{array}{c}\text { Kelompok } \\
\text { Statistik }\end{array}$ & $\begin{array}{c}\text { Berfikir } \\
\text { Kritis } \\
\text { Eksperimen }\end{array}$ & $\begin{array}{c}\text { Berfikir } \\
\text { Kritis } \\
\text { Kontrol }\end{array}$ & $\begin{array}{c}\text { Motivasi } \\
\text { Eksperimen }\end{array}$ & $\begin{array}{c}\text { Motivasi } \\
\text { Kontrol }\end{array}$ & $\begin{array}{c}\text { Hasil } \\
\text { Belajar } \\
\text { Eksperimen }\end{array}$ & $\begin{array}{c}\text { Hasil } \\
\text { Belajar } \\
\text { Kontrol }\end{array}$ \\
\hline $\mathbf{N}$ & $\mathbf{3 0}$ & $\mathbf{3 0}$ & $\mathbf{3 0}$ & $\mathbf{3 0}$ & $\mathbf{3 0}$ & $\mathbf{3 0}$ \\
\hline Mean & 71.8333 & 64.6667 & 71.6667 & 78.6000 & 77.0000 & 81.5333 \\
\hline Median & 71.5000 & 65.0000 & 70.0000 & 78.0000 & 80.0000 & 81.0000 \\
\hline Modus & $71.00^{\mathrm{a}}$ & 54.00 & 70.00 & 75.00 & 85.00 & 77.00 \\
\hline $\begin{array}{c}\text { Standar } \\
\text { Deviasi }\end{array}$ & 5.01091 & 7.54450 & 6.60895 & 4.63569 & 7.61124 & 4.27288 \\
\hline Range & 18.00 & 23.00 & 25.00 & 18.00 & 20.00 & 14.00 \\
\hline Maksimum & 81.00 & 77.00 & 85.00 & 88.00 & 85.00 & 89.00 \\
\hline Minimum & 2155.00 & 1940.00 & 2150.00 & 2358.00 & 2310.00 & 2446.00 \\
\hline
\end{tabular}

Mengacu pada tabel 1, tampak bahwa rata-rata kemampuan berfikir kritis pada pembelajaran problem solving adalah 71,83 lebih tinggi dibanndingkan siswa yang mengikuti pembelajaran konvensional dengan rata-rata 64.67. untuk motivasi belajar siswa yang mengikuti pembelajaran problem solving mempunyai nilai ratarata sebesar 71,67 lebih kecil dari siswa yang mengikuti pemebelajaran konvensional sebesar 78,60. Sedangkan untuk hasil belajar Ekonomi siswa yang menggunakan model pembelajaran problem solving mempunyai rata-rata sebesar 
77,00 lebih kecil dari hasil belajar Ekonomi menggunakan pemebelajaran konvensioanl yakni 81,53.

Untuk menguji hipotesis 1 dalam penelitian ini menggunakan uji levene model Independent sample tes yaitu diperoleh koefisien F sebesar 6.546 dengan signifikansi 0. 013 dan nilai thitung sebesar 4.334. Apabila ditetapkan signifikansi 0,05, nilai signifikansi jauh lebih kecil dari 0,05. Dengan demikian $\mathrm{H}_{\mathrm{o}}$ ditolak dan $\mathrm{H}_{1}$ diterima. Dengan demikian $\mathrm{H}_{\mathrm{o}}$ ditolak dan $\mathrm{H}_{1}$ diterima, jadi terdapat pengaruh antara model pembelajaran problem solving dengan kemampuan berfikir kritis.

Untuk menguji hipotesis 2 dalam penelitian ini menggunakan uji levene model Independent sample tes yaitu diperoleh koefisien F sebesar 5.341 dengan signifikansi 0.024 dan nilai thitung sebesar 4.704. Apabila ditetapkan signifikansi 0,05, nilai signifikansi jauh lebih kecil dari 0,05. Dengan demikian $\mathrm{H}_{\mathrm{o}}$ ditolak dan $\mathrm{H}_{1}$ diterima. Dengan demikian $\mathrm{H}_{\mathrm{o}}$ ditolak dan $\mathrm{H}_{1}$ diterima, jadi terdapat pengaruh antara model pembelajaran problem solving dengan motivasi belajar.

Untuk menguji hipotesis 3 dalam penelitian ini menggunakan uji levene model Independent sample tes yaitu diperoleh koefisien F sebesar 18.648 dengan signifikansi 0.001 dan nilai thitung sebesar 2.845 Apabila ditetapkan signifikansi 0,05, nilai signifikansi jauh lebih kecil dari 0,05. Dengan demikian $\mathrm{H}_{\mathrm{o}}$ ditolak dan $\mathrm{H}_{1}$ diterima. Dengan demikian $\mathrm{H}_{\mathrm{o}}$ ditolak dan $\mathrm{H}_{1}$ diterima, jadi terdapat pengaruh antara model pembelajaran problem solving dengan hasil belajar Ekonomi siswa.

Uji hipotesis 4 ini dilakukan dengan analisis MANOVA model Pillea Trace, wilk Lambda, Hotelling Trace, Roy's Largest Root. Hasil analisis data kemampuan berfikir kritis, motivasi dan hasil belajar Ekonomi menunjukkan harga $\mathrm{F}=18.401$ dengan signifikansi 0.001. Dari hasil tersebut nilai signifikansi lebih kecil dari 0.05 artinya secara simultan terdapat pengaruh antara kemampuan berfikir kritis, motivasi dan hasil belajar Ekonomi antara siswa yang mendapatkan perlakuan pembelajaran problem solving dengan siswa yang menggunakan pembelajaran konvensional

Pengujian terhadap hipotesis menunjukkan bahwa terdapat pengaruh yang signifikan antara siswa yang mendapatkan perlakuan model pembelajaran problem solving terhadap kemampuan berfikir kritis siswa. Hal ini dapat dilihat dari nilai $\mathrm{F}$ 
sebesar 5.341 dengan signifikansi 0.013 lebih kecil dari signifikansi 0.05. Selain itu analisis data deskriptif menunjukkan bahwa kemampuan berfikir kritis kelas eksperimen yang belajar dengan model pembelajaran problem solving berkategori cukup baik yaitu dengan rata rata skor 71.83, sedangkan kemampuan berfikir kritis siswa yang mengikuti model pembelajaran konvensional memilik rata rata skor sebesar 64.67 masih berkategori cukup baik. Siswa yang mendapatkan perlakuan model pembelajaran berbasisis masalah memiliki nilai rata rata sebanyak $26.67 \%$ sedangkan siswa yang mengikuti model pembelajaran konvensional sebanyak 16.67\%. Adanya hubungan yang signifikan antara kemampuan berfikir kritis siswa yang mendapatkan model pembelajaran problem solving menunjukkan bahwa model pembelajaran ini sangat baik untuk diterapkan oleh guru dalam proses belajar mengajar di kelas.

Tujuan pembelajaran problem solving adalah "membantu siswa mengembangkan kemampuan berfikir, memecahkan masalah, keterampilan intelektual, belajar tentang berbagai peran orang dewasa melalui pelibatan mereka dalam pengalaman nyata atau simulasi, dan menjadi pembelajaran yang mandiri”. (Nurhadi, dkk. 2004:58). Dalam pembelajaran problem solving, sebelum memulai proses belajar mengajar di dalam kelas, siswa terlebih dahulu diminta untuk mengobservasi suatu fenomena. Kemudian siswa diminta untuk mencatat permasalahan-permasalahan yang muncul. Setelah itu, tugas guru adalah merangsang siswa untuk berfikir kritis dalam memecahkan suatu masalah yang ada. Tugas guru adalah mengarahkan perspektif yang berbeda dengan mereka.

Berpikir kritis dan kreatif memungkinkan siswa untuk mempelajari masalah secara sistematis, menghadapi banyak rintangan dengan cara yang terorganisasi, merumuskan pertanyaan inovatif, dan merancang solusi yang tepat. Pada definisi lainnya, berpikir kritis adalah berpikir dengan baik, dan merenungkan tentang proses berpikir merupakan bagian dario berpikir dengan baik.

Penelitian ini relevan dengan hasil penelitian oleh Sadia, dkk(2009), Ida Bagus Purwata (2009), Lilik Farida (2010). Penelitian tersebut mengidentifikasikan bahwa terdapat pengaruh model pembelajaran problem solving terhadap keterampilan berfikir kritis siswa. 
Pengujian terhadap hipotesis menunjukkan bahwa terdapat pengaruh yang signifikan antara siswa yang mendapatkan perlakuan model pembelajaran problem solving terhadap motivasi belajar siswa. Hal ini dapat dilihat dari nilai $\mathrm{F}$ sebesar 4.704 dengan signifikansi 0.024 lebih kecil dari signifikansi 0.05. Selain itu analisis data deskriptif menunjukkan bahwa motivasi belajar siswa kelas eksperimen yang belajar dengan model pembelajaran problem solving berkategori cukup baik yaitu dengan rata rata skor 71.67, sedangkan motivasi belajar siswa yang mengikuti model pembelajaran konvensional memilik rata rata skor sebesar 78.60 masih berkategori cukup baik. Siswa yang mendapatkan perlakuan model pembelajaran problem solving memiliki nilai rata rata sebanyak $46.67 \%$ sedangkan siswa yang mengikuti model pembelajaran konvensional sebanyak $40.00 \%$. Selain kemampuan berfikir kritis, model pembelajaran problem solving juga mempengaruhi motivasi belajar siswa dalam mengikuti pelajaran. Djamarah, (2005:36) mengungkapkan bahwa "siswa yang memiliki motivasi cenderung akan menjadi orang yang terdidik, yang berpengetahuan, yang mempunyai keahlian dalam bidang tertentu". Dari pernyataan di atas dapat disimpulkan bahwa motivasi belajar sangat penting adanya, karena siswa yang memiliki motivasi belajar yang tinggi membuat siswa lebih fokus pada pelajaran sehingga tujuan pembelajaran dapat tercapai.

Penelitian ini relevan dengan hasil penelitian oleh Ida Bagus Parwata (2009),. Penelitian tersebut mengidentifikasikan bahwa terdapat pengaruh model pembelajaran problem solving terhadap motivasi belajar siswa. Hasil penelitian ini sejalan dengan hasil penelitian yang dilakukan oleh Farida (2010), bahwa model belajar berdasarkan masalah dapat meningkatkan motivasi belajar siswa dan aktivitas belajar siswa yang lebih baik dibandingkan dengan model pengajaran langsung.

Pengujian terhadap hipotesis menunjukkan bahwa terdapat pengaruh yang signifikan antara siswa yang mendapatkan perlakuan model pembelajaran berbasis masalah terhadap hasil belajar Ekonomi siswa. Hal ini dapat dilihat dari nilai $\mathrm{F}$ sebesar 2.845 dengan signifikansi 0.000 lebih kecil dari signifikansi 0.05. Selain itu analisis data deskriptif menunjukkan bahwa hasil belajar Ekonomi siswa kelas eksperimen yang belajar dengan model pembelajaran problem solving berkategori 
cukup baik yaitu dengan rata rata skor 77.00 sedangkan hasil belajar Ekonomi siswa yang mengikuti model pembelajaran konvensional memilik rata rata skor sebesar 81.53 erkategori baik. Siswa yang mendapatkan perlakuan model pembelajaran problem solving memiliki nilai rata rata sebanyak $56.67 \%$ sedangkan siswa yang mengikuti model pembelajaran konvensional sebanyak 33.33\%. Dalam kegiatan pembelajaran atau kegiatan instruksional, biasanya pendidik menetapkan tujuan belajar. Siswa yang berhasil dalam belajar adalah yang berhasil mencapai tujuan pembelajaran.

Setiap proses belajar mengajar keberhasilannya diukur dari seberapa jauh hasil belajar yang dicapai peserta didik, disamping diukur dari segi prosesnya, artinya seberapa jauh tipe hasil belajar dimiliki peserta didik (Sudjana,2004). Baik buruknya hasil dapat dilihat dari hasil pengukuran yang berupa evaluasi, selain mengukur hasil belajar, penilaian dapat juga ditujukan untuk mengetahui proses pembelajaran dan keaktifan peserta didik dalam mengikuti pembelajaran, maka seharusnya hasil belajar yang diperoleh peserta didik. dapat diketahui dan telah sesuai dengan tujuan yang telah dirumuskan.

Untuk mengetahui hasil belajar Ekonomi Terpadu pendidik seharusnya menggunakan proses pembelajaran yang telah ditetapkan oleh rencana pembelajaran serta mengumpulkan data dan informasi yang sesuai dengan standar kompetensi dan kompetensi dasar mata pelajaran Ekonomi. Hasil penelitian ini sejalan dengan hasil penelitian yang dilakukan oleh Farida (2010), bahwa model belajar berdasarkan masalah dapat meningkatkan motivasi belajar siswa dan aktivitas belajar siswa yang lebih baik dibandingkan dengan model pengajaran langsung.

\section{KESIMPULAN}

Berdasarkan hasil pengujian hipotesis dan pembahasan maka dapat dirumuskan kesimpulan sebagai berikut: 1). Terdapat pengaruh model pembelajaarn problem solving terhadap kemampuan berfikir kritis siswa kelas $\mathrm{X}$ SMAN 1 Masbagik. 2). Terdapat pengaruh model pembelajaarn problem solving terhadap motivasi belajar siswa kelas X SMAN 1 Masbagik. 3). Terdapat pengaruh 
model pembelajaarn problem solving terhadap hasil belajar Ekonomi siswa kelas X SMAN 1 Masbagik. 4). Terdapat pengaruh secara simultan penerapan model pembelajaarn problem solving terhadap kemampuan berfikir kritis siswa, motivasi dan hasil belajar Ekonomi siswa kelas X SMAN 1 Masbagik.

\section{DAFTAR RUJUKAN}

BSNP. ( 2006). Panduan Penyusunan Kurikulum Tingkat satuan Pendidikan Jenjang Pendidikan Dasar dan Menengah. Jakarta : Badan Standar Nasional Pendidikan.

Djamarah, Syaiful Bahri. 2005. Guru dan anak didik dalam interaksi edukatif: suatu pendekatan teoritis psikologis. Jakarta: Rineka Cipta.

Farida, Lilik. 2010. Penerapan Model Pembelajaran Problem solving Untuk meningkatkan Motivasi dan Aktivitas Belajar di SMA Negeri 2 Malang. Tesis tidak diterbitkan. Malang: Fakultas MIPA, Universitas Negeri Malang

Ida Bagus Parwata. 2009 Pengaruh Pembelajaran problem solving Terhadap Motivasi Berprestasi dan Hasil Belajar Matematika Pada Siswa Kelas X SMA Negeri 1 Banjar. Tesis (tidak diterbitkan) Program Pasca Sarjana, Universitas Pendidikan Ganesha.

Johnson, Elaine B. 2002. Contextual Teaching and Learning. Menjadikan Kegiatan Belajar Mengajar Mengasikkan dan Bermakna. Bandung: PT. MLC.

Nurhadi, dkk. 2004. Pembelajaran Kontekstual dan Penerapannya Dalam KBK. Malang: UM Press.

Sadia. 2008 Pengaruh Model Pembelajaran Problem Solving Untuk meningkatkan Keterampilan Berpikir Kritis dan Prestasi belajar Siswa Kelas I-c SMA Negeri 5 Malang. Tesis tidak diterbitkan. Malang: Fakultas MIPA, Universitas Negeri Malang

Sujana, N. 2004. Penilaian Hasil Proses Belajar Mengajar. Bandung: PT. Remaja Rosda Karya.

Sutanto. 2005. Motivasi belajar Mengajar dalam Berinteraksi. : Raja Grafindo Persada.

Winkel, W.S. 1999. Psikologi Pengajaran. Jakarta: Gramedia Widiasarana Indonesia. 
Muspita, Sholihah, Pengaruh model Pembelajaran Problem Solving Terhadap Kemampuan Berfikir...

JPEK, Vol. 3, No. 1, Juni 2019. 